\title{
Anterior capsule staining using $0.025 \%$ trypan blue in cataracts without red reflex
}

\author{
Usode azul tripano a 0,025\% para corar a cápsula anterior em catarata sem reflexo
}

\author{
Eduardo Ferrari Marback ${ }^{1}$ \\ Lincoln Lemes de Freitas ${ }^{2}$ \\ Fernanda Peleg'rino Fernandes ${ }^{3}$ \\ Bruno Castelo Branco ${ }^{4}$ \\ Rubens Belfort Jr. ${ }^{5}$
}

\begin{tabular}{|l|}
\hline ABSTRACT \\
\hline Purpose: To describe the use of anterior capsule staining in cataracts \\
without red reflex using a $0.025 \%$ trypan blue solution. Methods: Six \\
eyes of 6 patients with cataracts without red reflex were submitted to \\
phacoemulsification using a direct injection of 0.2 to 0.5 ml of $0.025 \%$ \\
trypan blue in the anterior chamber previous to viscoelastic injection. \\
All patients had an ophthalmologic examination prior to surgery, as well \\
as pre and postoperative corneal endothelial cell count. Results: In all \\
cases the capsule became stained with a faint blue color that enabled \\
an adequate visibility of the flap during the continuous curvilinear \\
anterior capsulotomy (CCC). There were no intra-or postoperative \\
complications. The endothelial cell loss varied between $1.8 \%$ and $26.6 \%$ \\
(mean 12.8\%). Conclusion: Staining the anterior capsule with $0.025 \%$ \\
trypan blue solution allows a good visibility of the capsular flap and \\
facilitates the confection of CCC in cataracts without red reflex. \\
\hline
\end{tabular}

Keywords: Cataract; Cataract extraction; Lens capsule; Crystalline/surgery; Trypan blue/ therapeutic use; Dyes

\section{INTRODUCTION}

The continuous circular capsulotomy (CCC) that was introduced by Gimbel and Neuhann ${ }^{(1)}$ in 1990 is resistant to radial tears during the various surgical steps and also offers the advantages of in the bag intraocular lens (IOL) implantation. Another advantage of CCC is the opportunity of a safe sulcus IOL implantation over the anterior capsule rim in cases of a posterior capsule rupture. For a good control when performing a $\mathrm{CCC}$, the visualization of the anterior capsular flap is necessary and the lack of an adequate red reflex renders the technique very difficult.

Many techniques have been proposed to help the surgeon to perform a CCC in cataracts without red reflex ${ }^{(2-9)}$.

The purpose of this report is to describe the use of $0.025 \%$ trypan blue solution to allow better anterior capsular flap visibility and a safe CCC in cataracts without red reflex. Trypan blue has classically been used to identify damaged endothelial cells and safety has been proved in donor corneal buttons ${ }^{(10)}$, as well as in extracapsular cataract extraction ${ }^{(11)}$.

\section{METHODS}

Six eyes of 6 patients with cataracts without red reflex and no further known ocular disease were submitted to phacoemulsification and IOL im- 
plantation. The ages varied between 52 and 79 years (mean 68). All surgeries were done by the same surgeon (LLF), using the same equipment (Leggacy $20000^{\circledR}$ - Alcon), under peribulbar anesthesia, with a three-plane clear corneal incision, the "stop and chop"(12) technique and an implant with a $5.25 \mathrm{~mm}$ optical zone.

After the ancillary paracenthesis, made in the limbus $90^{\circ}$ away from the area where the clear cornea incision should be done, 0.2 to $0.5 \mathrm{ml}$ of $0.025 \%$ trypan blue was injected in the anterior chamber, followed by filling of the anterior chamber with a viscoelastic solution, leaving the anterior capsule with a faint blue coloration. After the clear corneal incision, CCC was performed using the Ultrata forceps. The $0.025 \%$ trypan blue solution was obtained by diluting $0.1 \mathrm{ml}$ of the $0.1 \%$ commercially available solution (Ophthalmos - São Paulo, Brazil) in $0.3 \mathrm{ml}$ of balanced salt solution (BSS ${ }^{\circledR}$, Alcon). The total effective used ultrasound power was recorded for each case.

At the end of surgery dexametasone and gentamicin were injected in the subconjunctival space. Patients were seen on the $1^{\text {st }}, 6^{\text {th }}, 30^{\text {th }}$ and $40^{\text {th }}$ postoperative day and received a combination of $1 \mathrm{mg}$ dexametasone, $5 \mathrm{mg}$ neomicine sulfate and $6000 \mathrm{IU}$ polymyxin B sulfate eyedrops (Maxitrol ${ }^{\circledR}$ - Alcon) 6 times a day in the first postoperative week with gradual tapering of the dose in the following 3 weeks.

All patients had visual acuity, intraocular pressure (IOP) and anterior chamber reaction evaluated before surgery and on days 1, 6, 30 and 40. Endothelial cell count was performed prior to surgery and on day forty.

\section{RESULTS}

CCC was successfully performed in all eyes. In 2 of them it was necessary to inject more viscoelastic after the initial capsular puncture because of liquefied cortical material leakage. The contrast between the stained capsular flap and the white cortical material allowed a safe control of the CCC progression and the remaining anterior capsule edge was still stained during phacosculpture. By the time of cortical aspiration, the faint blue coloration had disappeared from the anterior capsule rim. The remaining surgical steps were uneventful.

On the first postoperative day, mild corneal edema was seen in 1 eye and moderate edema in 5 eyes. By the $6^{\text {th }}$ postoperative day the edema had vanished in all cases. There was no increase in IOP or any evidence of residual stain in the anterior segment during the postoperative period. A mild (+) cellular anterior chamber reaction was present on day 1 in the 6 eyes and had disappeared by day 6 .

The visual acuity, IOP and endothelial cell count before surgery and on day 40 are showed in Table 1 . The endothelial cell loss varied between 1.85 to $26.6 \%$ (mean of $12.8 \%$ ).

\section{DISCUSSION}

Many techniques have been suggested to improve safety in CCC confection of cataracts without red reflex, such as the

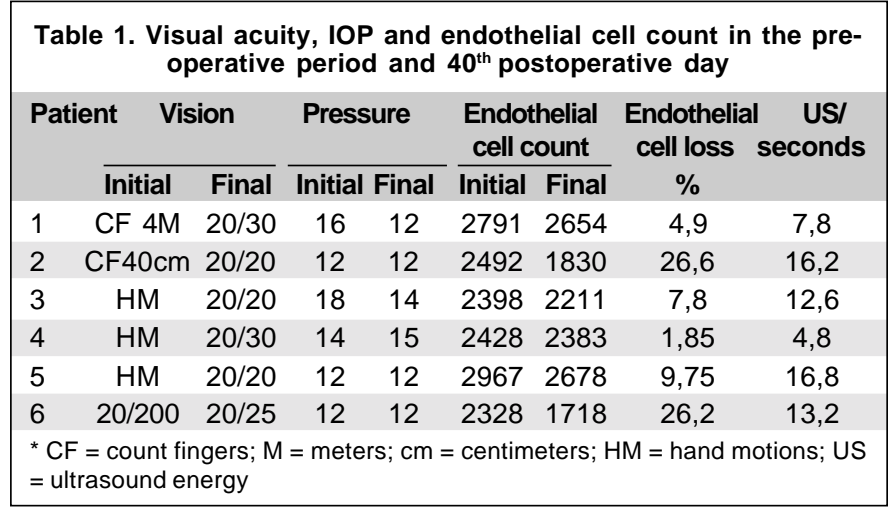

use of a optic fiber endoilluminator in a lateral position ${ }^{(7)}$, endodiathermy ${ }^{(5)}$, air filling of the anterior chamber ${ }^{(2)}$, twostep CCC under high magnification ${ }^{(3)}$, autologous blood impregnation $^{(8)}$ and the injection of various vital stains in the anterior chamber like a solution of gentian violet and methylene blue, brilliant cresyl blue, fluorescein, trypan blue $0.1 \%$ and indocianine green ${ }^{(4,6,9)}$. The endoilluminator and the endodiathermy imply in additional costs with sophisticated devices, and the endodiathermy capsulotomy is considered weaker than the traditional $\mathrm{CCC}^{(5)}$. The two-step CCC involves a change in the emulsification technique to work within a small $\mathrm{CCC}$ and the additional risk of a radial tear or peripheral escape during the enlargement of the primary CCC.

Among the vital stains, brilliant cresyl blue has never been used in vivo; the gentian violet and methyilene blue solutions result in corneal edema and endothelial decompensation $^{(9)}$, fluorescein must be injected underneath the anterior capsule, staining the lens epithelium, not the capsule itself $f^{(4)}$ and it can stain the cornea and lens cortex also ${ }^{(6)}$. Indocianine green seems to be a good option ${ }^{(6)}$, but it is expensive, not available in a fractionated fashion, has a life span of only 8 hours after dilution and must be kept protected from light.

Trypan blue is a vital stain classically used to evaluate damaged endothelial cells, presenting no toxicity in concentrations as high as $0.3 \%^{(11)}$. Since it does not stain the healthy endothelial cells, it poses no risk of lowering intraoperative visibility. The safety of intraoperative use of trypan blue in extracapsular cataract surgery has already been proved with follow-up periods up to 8 years ${ }^{(11)}$.

Recently Melles et al. ${ }^{(9)}$ reported the use of $0.1 \%$ trypan blue to perform CCC in cataracts without red reflex. They advocated the use of an air bubble in the anterior chamber with injection of the stain between the air and the anterior capsule to prevent its dilution ${ }^{(9)}$. We used the injection of a $0.025 \%$ solution without an air bubble in the chamber and achieved sufficient capsular staining. Injecting the dye between an air bubble and the capsule is not a easy maneuver and the size of the bubble is critical, since it can prevent the complete staining of the anterior capsule. CCC was safely 
performed with postoperative corneal findings similar to those usually seen in surgeries without it. Additionally, using a solution that is diluted starting from its original commercial presentation, without performance decay, represents a cost reduction that is an important goal of present medicine. Another possible application of capsular staining is in the training of new surgeons, since the improvement in flap visibility may help to control its progression for beginners even when the cataract has a good red reflex.

\section{ACKNOWLEDEMENT}

The authors wish to thank Farmácia Ophthalmos for kindly supplying trypan blue solution to this study.

\section{RESUMO}

Objetivo: Relatar o uso de uma solução de azul tripano a $0,025 \%$ para corar a cápsula anterior em cataratas sem reflexo. Métodos: Seis olhos de 6 pacientes portadores de catarata sem reflexo foram submetidos à facoemulsificação com injeção direta de azul tripano a $0,025 \%$ na câmara anterior previamente à injeção de solução viscoelástica. Todos os pacientes tiveram exame oftalmológico prévio à cirurgia incluindo contagem de células endoteliais no pré-operatório e no $40^{\circ}$ dia pós-operatório. Resultados: Em todos os casos a cápsula anterior adquiriu uma tonalidade azul clara que permitiu uma boa visibilidade e controle da progressão durante a capsulotomia curvilínea contínua (CCC). Não houve complicação intra ou pós-operatória. A perda endotelial variou entre 1,8\% e 26,6\% (média 12,8\%). Conclusão: O uso de azul tripano a $0,025 \%$ para corar a cápsula anterior permite uma boa visibilidade do "flap", facilitando a confecção da CCC em cataratas sem reflexo.

Descritores: Catarata; Extração de catarata; Cápsula do cristalino; cristalino/cirurgia; Corantes; Azul tripano/uso terapêutico; Capsulotomia

\section{REFERENCES}

1. Gimbel HV, Neuhann T. Development, advantages, and methods of continuous circular capsulorhexis technique. J Cataract Refract Surg 1990;16: 31-7.

2. Brusini P. Capsulorhexis in mature cataracts: Why not? Doc Ophthalmol 1992;81:281-4.

3. Gimbel HV. Two-stage capsulorhexis for endocapsular phacoemulsification. J Cataract Refract Surg 1990;16:246-9.

4. Hoffer KJ, McFarland JE. Intracameral subcapsular fluorescein staining for improved visualization during capsulorhexis in mature cataracts [letter]. J Cataract Refract Surg 1993;19:566.

5. Findl O, Amon M. Anterior capsulotomy created by radiofrequency endodiathermy and continuous curvilinear posterior capsulorhexis in a patient with intumescent cataract and primary capsular fibrosis. J Cataract Refract Surg 1998;24:870-1.

6. Horiguchi M, Miyake K, Ohta I, Ito Y. Staining of the Lens Capsule for Circular Continuous Capsulorhexis in Eyes With White Cataract. Arch Ophthalmol 1998;116:535-7.

7. Mansur AM. Anterior capsulorhexis in hypermature cataract [letter]. J Cataract Refract Surg 1993;19:116-7.

8. Cimetta DJ, Gatti M, Labianco G. Hemocoloration of the anterior capsule in white cataract CCC. Eur J Implant Refract Surg 1995;7:184-5.

9. Melles GR, de Waard PW, Pameyer JH, Houdijn Beekhuis W. Trypan blue capsule staining to visualize the capsulorhexis in cataract surgery. J Cataract Refract Surg 1999;25:7-9.

10. Almada AT. Coloração Vital. In: Belfort Jr R, Kara José N. Córnea. Clínica Cirúrgica. Rio de Janeiro:Roca; 1997. cap. 12.

11. Norn MS. Per operative trypan blue vital staining of corneal endothelium. Eight years' follow up. Acta Ophthalmol (Copenh) 1980;58:550-5.

12. Koch S, Katzen LE. Stop and chop phacoemulsification. J Cataract Refract Surg 1994;20:566-70.

\title{
I Simpósio do Instituto de Oftalmologia Professor Ivo Corrêa-Meyer
}

\author{
26 e 27 de Outubro de 2001 \\ Porto Alegre - RS
}

INFORMAÇÕES: Tel: (00xx51) 346-3636

e-mail: iicm@ig.com.br 